\title{
Efficacy of Bio-agents and Botanicals In-vitro and Integrated Disease Management of Wilt Disease of Chilli caused by Fusarium oxysporum f. sp. capsici
}

\author{
Abhinav*, Pushpendar Singh Shekhawat and Abhilasha A. Lal \\ Department of Plant Pathology, Faculty of Agriculture, Sam Higginbottom Institute of \\ Agriculture, Technology and Sciences (Deemed to be University) Allahabad - 211 007, \\ Uttar Pradesh, India \\ *Corresponding author
}

\section{A B S T R A C T}

\section{Keywords}

Capsicum annuum, Carbendazim 50 WP, Fusarium oxysporum f.sp. capsici, in-vitro, Neem leaf extract, Pseudomonas fluorescens, Trichoderma spp

Article Info

Accepted: 20 June 2021 Available Online: 10 July 2021
Fusarium wilt has become a serious problem in recent years in all chilli growing irrigated tracts of India. Wilt of chilli (Capsicum annuиm) caused by Fusarium oxysporum f.sp. capsici. In present investigation bio-agents, botanicals and fungicide were evaluated in-vitro and in vivo condition against Fusarium oxysporum. Among all the treatments Trichoderma viride was found most effective in inhibiting $(80.87 \%)$ of mycelial growth of Fusarium oxysporum f.sp. capsici followed by Pseudomonas fluorescens (78.00\%), T. harzianum (76.08\%), neem leaf extract @ 10\% (53.11\%) and jatropha leaf extract @ 10\% (33.50\%) as compared to treated check carbendazim 50 WP $(91.87 \%)$ and untreated check $(0 \%)$ under in vitro laboratory condition. A total of seven treatments, replicated three times were taken up in randomized block design. All treatments were significantly increased plant height, root length, fresh and dry shootroot weight and yield per plant. Among all the treatments the minimum wilt incidence was recorded in treatment $\mathrm{T}_{1^{-}}$carbendazim $50 \mathrm{WP}$ seed treatment (ST) $(8.33 \%)$, followed by $\mathrm{T}_{3}-$ Trichoderma viride (ST) (13.88\%), $\mathrm{T}_{2}-$ T. harzinum (ST) (19.44\%), $\mathrm{T}_{4^{-}}$P. fluerscence (ST) (16.66\%), $\mathrm{T}_{5^{-}}$Neem leaf extract (ST) @ 10\% (25.00\%), $\mathrm{T}_{6^{-}}$ Jatropha leaf extract (ST) @ 10\% (33.33\%) and maximum percent disease incidence was found in $\mathrm{T}_{0^{-}}$control $(44.44 \%)$.

\section{Introduction}

Chilli is an important vegetable and spice crop and it belongs to the family solanaceae. Capsicum annuum L. and Capsicum frutescence L. are two important species cultivated in several tropical and sub tropical climates both for green and ripen dry fruit. The medicinal value of chilli is much realized because of its vitamins ' $\mathrm{C}$ ' and capsaicin contents. The fruits contain $85.7 \%$ water, $1.2 \%$ protein, $0.6 \%$ fat, $1.0 \%$ mineral, $3.0 \%$ carbohydrates, $6.8 \%$ fiber, $0.03 \%$ calcium, $0.24 \%$ magnesium, $0.01 \%$ iron, $0.20 \%$ 
potassium, 0.34\% sulphur, 292 I.U. of vitamin A, $111 \mathrm{mg}$ vitamin $\mathrm{C}$ and some per cent of thiamine, riboflavin and nicotinic acid (Muthukrishnan et al., 1993).

India is the largest producer of red chilli, followed by China, Mexico and Pakistan. Fusarium wilt has become a serious problem in recent years in all chilli growing irrigated tracts of India where the crop is grown especially in black cotton soil leading up to $20 \%$ yield loss (Rani et al., 2007).

Worldwide wilt disease of chilli caused by Fusarium oxysporum f. sp. capsici resulted the highest yield losses of 45-62\%. The pathogen enter to the plant system via roots and colonize the vascular tissues, blocking the water and nutrients transport that leads to yellowing of older leaves. Roots and stems develop a dark-brown discoloration of xylem tissues that can be seen when they are split vertically or cross-sectioned (Schwartz et al., 2005). Nowadays, the fungicides are being used for the management of plant diseases in an effective mannered as these compounds have direct effect on the pathogen (Jamil and Kumar, 2010). Beside, solely and repeated use of fungicides cause harmful effect to the environment and pollute to the soil by residual effect.

Likewise, organic amendments also play an important in the control of the plant pathogens. Apart from pathogen control it enhances the plant growth, soil fertility and increases the beneficial soil microorganisms (Lazarovits et al., 2001). So farmers can use integration of bio-control agents and organic amendments along with minimum use of fungicides to suppress the disease and reduce environmental pollution as well as economic purpose. Present study showed the efficacy of bio-agents, botanicals and fungicides against Fusarium oxysporum f.sp. capsici under laboratory condition and field condition.

\section{Materials and Methods}

The study was conducted on in-vitro and invivo evaluation of bio-agents and botanicals against the Fusarium oxysporum f. sp. capsici. In the department of plant pathology, Sam Higginbottom institute of Agriculture, Technology \& Sciences. The efficacy of bioagents, botanicals and fungicide against Fusarium oxysporum f.sp. capsici was assessed by inhibition of radial growth of mycelia by dual culture technique and poison food technique and found best effective treatments under laboratory condition were used in field conditions.

\section{Isolation of pathogen}

The Fusarium oxysporum was isolated from wilted chilli plants and maintained in pure culture on Potato Dextrose Agar (PDA) (Chakraborty and Chatterjee, 2007). Infected portions of diseased plants were cut into small pieces using a sterilized scalpel and then surface sterilized with $0.1 \%$ mercuric chloride for one minute, washed three times in sterile distilled water, and placed on solidified PDA in Petri dishes. The plates were incubated at room temperature $\left(28+2^{\circ} \mathrm{C}\right)$ for five days. Fungal hyphal tips were transferred aseptically to PDA slants for maintenance of the culture. The pathogen was identified based on cultural and morphological characters and confirmed from ITCC, New Delhi.

\section{Pathogenicity test}

Pathogenecity of the isolated organism Fusarium oxysporum f.sp. capsici was proved under glass house condition by implying Koch's postulate. The isolated fungus was multiplied in $100 \mathrm{ml}$ Potato Dextrose broth medium in $250 \mathrm{ml}$ conical flask. A nine $\mathrm{mm}$ disk of seven days old fungal culture was placed in each flask containing $100 \mathrm{ml}$ broth and incubated at $25 \pm 2^{\circ} \mathrm{C}$ for seven days. 
After incubation the entire fungal mat bearing conidia from each flask was macerated in mortar-pestle and macerated fungal growth was suspended in $100 \mathrm{ml}$ distilled water and spores concentration was maintained at $2 \times$ $10^{6}$ conidia per $\mathrm{ml}$. Test seedlings of 25-35 days old were removed very carefully and dipped into the spore suspension for at least 5 minutes. The seedlings were then transplanted back in their respective pots. Three replications were maintained for culture and control. Observations of wilt disease were recorded after appearance of symptoms.

\section{Preparation of plant extracts}

The fresh leaves of neem and jatropha were grounded in a pestle and mortar by using sterile distilled water. The extract was filtered through double layered muslin cloth and made to the required concentration by adding distilled water.

In the present study different concentrations of extracts of plant leaves of Neem and Jatropha were evaluated for their effect on the spore germination of $F$. oxysporum. For the preparation of different concentrations of plant extracts, $200 \mathrm{~g}$ each of leaves were washed with sterilized distilled water, grinded in Mortor and pestle using $200 \mathrm{ml}$ of sterilized distilled water (Bhat and Sivaprakasan, 1994). The material was homogenized for 5 minutes and filtered through double layered muslin cloth followed by Whattman's filter paper No. 1. The filtrate was then centrifuged at 5000 rpm for 10 minutes and considered as standard solutions and were used to study the spore germination of $F$. oxysporum.

\section{Effect of fungicide on Fusarium oxysporum f.sp. capsici by poison food technique}

The efficacy of fungicide Carbendazim $50 \mathrm{WP}$ was evaluated against Fusarium oxysporum f.sp. capsici using poisoned food technique.
The sterilized PDA medium along with fungicide solution poured into the sterilized Petri plates@20 ml per plate. Culture disc (9 $\mathrm{mm}$ cut from pathogen by using sterilized Cork borer) of tested pathogen were taken from seven days old culture and transferred aseptically to $90 \mathrm{~mm}$ petri plate in the centre.

The PDA medium without fungicidal solution kept as control and inoculated plates were incubated in BOD incubator at $27 \pm 1^{\circ} \mathrm{C}$ for seven days. Three replications were observed for each treatment. Percent growth inhibition of pathogen over control was calculated by using the formula given by Vincent, (1947).

Percent growth inhibition $(\mathrm{I})=\mathrm{C}-\mathrm{T}$ X 100/ C

Where, $\mathrm{C}=$ Growth of test fungus in control in $\mathrm{mm}$. $\mathrm{T}=$ Growth of test fungus in treatment in $\mathrm{mm}$

\section{In-vitro evaluation of bio-agents}

Antagonistic microorganisms like, Trichoderma viride, T. harzianum and Pseudomonas fluorescens were evaluated for their antagonistic properties against Fusarium oxysporum f. sp. capsici by dual culture technique. Twenty millilitre of PDA was poured into sterilized Petri plates. Fungal antagonists were evaluated by inoculating the pathogen at one side of the Petri plate and the antagonist inoculated at exactly opposite side of the same plate by leaving 3-4 cm gap. For this actively seven days old growing cultures were used. In case of bacterial antagonist's evaluation, two mycelial discs of pathogen were inoculated and bacterial antagonist was streaked in the centre of the plate. One untreated control was maintained where only test fungus was grown. The treatments were replicated three times. The plates were incubated for seven days at $27 \pm 1 \mathrm{C}$. After incubation the colony diameter of Fusarium oxysporum f. sp. capsici was recorded. Percent 
inhibition was calculated by using the formula given by Vincent, (1947).

\section{In-vitro evaluation of plant extracts}

The efficacy of plant extracts were evaluated against Fusarium oxysporum f. sp. capsici using poisoned food technique. The sterilized PDA medium along with desired plant extract solution poured into the sterilized Petri plates (a) $20 \mathrm{ml}$ per plate. Culture disc (9mm cut from pathogen by using sterilized Cork borer) of tested pathogen were taken from seven days old culture and transferred aseptically to 90 $\mathrm{mm}$ petri plate in the centre. The PDA medium without plant extract solution kept as control and inoculated plates were incubated in BOD incubator at $27 \pm 1^{\circ} \mathrm{C}$ for seven days. Three replications were observed for each treatment. Percent growth inhibition of pathogen over control was calculated by using the formula given by Vincent, (1947).

Percent growth inhibition $(\mathrm{I})=\mathrm{C}-\mathrm{T}$ X 100/ C

Where, $\mathrm{C}=$ Growth of test fungus in control in $\mathrm{mm}$. $\mathrm{T}=$ Growth of test fungus in treatment in $\mathrm{mm}$.

\section{Evaluation of fungicides, bio-control agent} and botanicals against Fusarium oxysporum f.sp. capsici under field condition

The experiment was laid out in a single randomized block design (RBD) with seven treatments including untreated control and treated control, each replicated three times. $\left(\mathrm{T}_{0}\right)$ without treatment as control (untreated check), $\left(\mathrm{T}_{1}\right)$ carbendazim 50 WP (treated check) seed treatment @ $2 \mathrm{~g} \mathrm{~kg}^{-1}, \quad\left(\mathrm{~T}_{2}\right)$ Trichoderma harzianum seed treatment @6g $\mathrm{kg}^{-1}$, ( $\left.\mathrm{T}_{3}\right)$ Trichoderma viride seed treatment @ $6 \mathrm{~g} \mathrm{~kg}^{-1},\left(\mathrm{~T}_{4}\right)$ Pseudomonas fluorescens seed treatment@6g kg-1,$\left(\mathrm{T}_{5}\right)$ neem leaf extract seed treatment @10\% and $\left(\mathrm{T}_{6}\right)$ jatropha leaf extract seed treatment @10\%.

\section{Results and Discussion}

The inhibition percent of radial growth of mycelia among the treatments was significant. Among the bio-agents and botanicals maximum inhibition percent of radial growth was recorded in $\mathrm{T}_{3}$ - Trichoderma viride $(80.87 \%)$ as compared to the treated and untreated controls $(91.87 \%$ and $0 \%$, respectively). $\mathrm{T}_{3}$ - Trichoderma viride $(80.87 \%)$ was followed by $\mathrm{T}_{4}-$ Pseudomonas fluorescens (78.00\%), $\mathrm{T}_{2}-T$. harzianum (76.08\%), $\mathrm{T}_{5}$ - neem leaf extract $(53.11 \%)$, and $\mathrm{T}_{6}-$ jatropha leaf extract $(33.50 \%)$.

The present investigation under in vitro condition revealed that, the inhibition percent of radial growth of mycelia among the treatments was significant. Among the bioagents and botanical maximum inhibition percent of radial growth was recorded in $\mathrm{T}_{3}$ Trichoderma viride $(80.87 \%)$ as compared to the treated (carbendazim 50 WP) and untreated controls $(91.87 \%$ and $0 \%$, respectively). $\mathrm{T}_{3}$ - Trichoderma viride $(80.87 \%)$ was followed by $\mathrm{T}_{4}-$ Pseudomonas fluorescens (78.00\%), $\mathrm{T}_{2}-T$. harzianum (76.08\%), $\mathrm{T}_{5}-$ neem leaf extract $(53.11 \%)$, and $\mathrm{T}_{6}-$ jatropha leaf extract $(33.50 \%)$.

The maximum plant height $(\mathrm{cm})$, among the bio-agents and botanicals was recorded in $\mathrm{T}_{3}$ Trichodermaviride @6g kg-1 $(53.27 \mathrm{~cm})$ as compared to the treated (carbendazim $50 \mathrm{WP}$ ) and untreated controls $(57.43 \mathrm{~cm}$ and 38.78 $\mathrm{cm}$, respectively). $\mathrm{T}_{3}$ - Trichoderma viride @ $6 \mathrm{~g} \mathrm{~kg}^{-1}(53.27 \mathrm{~cm})$ was followed by $\mathrm{T}_{4^{-}}$ Pseudomonas fluorescens @6g kg-1 (50.52 $\mathrm{cm}), \mathrm{T}_{2}$ - T. harzianum @ $6 \mathrm{~g} \mathrm{~kg}^{-1}(48.52 \mathrm{~cm})$, $\mathrm{T}_{5}$ - Neem leaf extract@10\% (45.78 cm), and $\mathrm{T}_{6}-$ Jatropha leaf extract @ 10\% (42.30 $\mathrm{cm})$.

The result presented in Table 2 revealed that all the treatments were statistically significant and decreased disease incidence as compared 
to untreated check. At 90 days after transplanting minimum disease incidence was recorded in $\mathrm{T}_{3^{-}}$Trichoderma viride $(13.88 \%)$ followed by $\mathrm{T}_{4^{-}}$Pseudomonas fluorescens (16.66\%), $\mathrm{T}_{2^{-}}$T. harzianum (19.44\%), $\mathrm{T}_{5^{-}}$ Neem leaf extract (25.00\%), $\mathrm{T}_{6^{-}}$Jatropha leaf extract $(33.33 \%)$, as compared to treated check Carbendazim 50 WP (8.33\%) and untreated Check - Control (44.44\%).

Seed treatment with Trichoderma viride @6g $\mathrm{kg}^{-1}$ was found to be most effective in fresh and dry root weight $(15.88 \mathrm{~g}, 7.86 \mathrm{~g}$, respectively) followed by $P$. fluorescens (14.19 g, $6.89 \mathrm{~g}$, respectively), T. harzianum (13.31 g, $6.16 \mathrm{~g}$, respectively), neem leaf extract (11.86 g, $5.25 \mathrm{~g}$, respectively) and jatropha leaf extract(9.83 g, 4.11 g, respectively as compared to treated check Carbendazim 50 WP (18.14 g, $9.29 \mathrm{~g}$, respectively) and untreated Check - Control (7.85 g, $2.27 \mathrm{~g}$, respectively).

The maximum root length $(\mathrm{cm})$, among the bio-agents and botanicals was recorded in $\mathrm{T}_{3}$ Trichodermaviride @ $6 \mathrm{~g} \mathrm{~kg}^{-1}(18.20 \mathrm{~cm})$ as compared to the treated (carbendazim 50 WP) and untreated controls $(20.26 \mathrm{~cm}$ and $9.34 \mathrm{~cm}$, respectively). $\mathrm{T}_{3}$ - Trichoderma viride @6 $\mathrm{g}$ $\mathrm{kg}^{-1}(18.20 \mathrm{~cm})$ was followed by $\mathrm{T}_{4^{-}}$ Pseudomonas fluorescens @ $6 \mathrm{~g} \mathrm{~kg}^{-1}$ (17.37 $\mathrm{cm}), \mathrm{T}_{2}$ - T. harzianum @ $6 \mathrm{~g} \mathrm{~kg}^{-1}(16.50 \mathrm{~cm})$, $\mathrm{T}_{5}$ - neem leaf extract @ 10\% $(15.46 \mathrm{~cm})$, and $\mathrm{T}_{6}$ - jatropha leaf extract @ 10\% $(14.22 \mathrm{~cm})$.

Seed treatment with Trichoderma viride @6g $\mathrm{kg}^{-1}$ was found to be most effective in fresh and dry shoot weight $(18.15 \mathrm{~g}, 7.82 \mathrm{~g}$, respectively) followed by $P$. fluorescens (17.87 g, $6.54 \mathrm{~g}$, respectively), T. harzianum (16.56 g, 5.72g, respectively), neem leaf extract (14.39 g, $5.71 \mathrm{~g}$, respectively) and jatropha leaf extract $(12.57 \mathrm{~g}, \quad 4.30 \mathrm{~g}$, respectively) as compared to treated check carbendazim 50 WP (20.88 g, 9.36g, respectively) and untreated Check - Control (9.17 g, $2.36 \mathrm{~g}$, respectively). Biological control through the use of antagonistic microorganisms is a potential, non- chemical means of controlling plant disease by reducing inoculum levels of the pathogens.

Such a management can help in preventing the pollution and also health hazards. In the present investigation, the antagonistic effect of different bio-agents was assessed against Fusarium oxysporum f. sp. capsici by dual culture technique. $T$. viride was most effective followed by Pseudomonas fluorescens, this could be obviously due to several possibilities of existence of microbial interactions such as stimulation, inhibition, mutual intermingling of growth of antagonistic isolate over test pathogen which have been enumerated by many workers (Meena et al., 2011 and Singh et al., 2015).

Effect of bio-agents due to hyperparasitism/ mycoparasitism, competition for space and nutritional source and antagonistic chemical produced by them. $T$. viride have been reported to produce antibiotic compounds (Trichodermin) extracellular enzymes (chitinase, cellulase) unsaturated monobasic acids (Dermadine) and peptides that may have damaged plant pathogen. Trichoderma metabolities that may hence acted as elicitors of plant resistance or the expression in transgenic plants of genes whose products act as elicitors, also results in synthesis and in an increase in resistance against pathogen (Islam and Faruq, 2008). Trichoderma viride may be due to bio-control agents are responsible for production of plant hormones, vitamins, conversion of non-utilizable materials into a form that can be utilize by the plant and increased uptake and translocation of minerals. Increase the efficiency of nutrient uptake solubilizing certain insoluble nutrient element like rock phosphate. 
Table.1 In-vitro inhibition of radial mycelial growth of Fusarium oxysporum f. sp. capsici as affected by treatments

\begin{tabular}{|c|c|c|}
\hline \multicolumn{4}{|c|}{ Treatments } & (Inhibition (\%) \\
\hline $\mathbf{T}_{\mathbf{0}}$ & Untreated Check & 0 \\
\hline $\mathbf{T}_{\mathbf{1}}$ & Treated Check (Carbendazim 50 WP) & 91.87 \\
\hline $\mathbf{T}_{\mathbf{2}}$ & Trichoderma harzianum & 76.08 \\
\hline $\mathbf{T}_{\mathbf{3}}$ & Trichoderma viride & 80.87 \\
\hline $\mathbf{T}_{\mathbf{4}}$ & Pseudomonas fluorescens & 78.00 \\
\hline $\mathbf{T}_{\mathbf{5}}$ & Neem leaf extract @ 10\% & 53.11 \\
\hline $\mathbf{T}_{\mathbf{6}}$ & Jatropha leaf extract @ 10\% & 33.50 \\
\hline
\end{tabular}

Table.2 Evaluation of different integrated management strategies against

Fusarium wilt disease of chilli

Treatment Disease incidence (\%) Plant height $(\mathrm{cm}) \quad$ Root length $(\mathrm{cm})$

\begin{tabular}{llccc}
\hline $\mathrm{T}_{0}$ & Control & 44.44 & 38.78 & 9.34 \\
$\mathrm{~T}_{1}$ & Carbendazim 50 WP & 8.33 & 57.43 & 20.26 \\
$\mathrm{~T}_{2}$ Trichoderma harzianum & 19.44 & 48.52 & 16.50 \\
$\mathrm{~T}_{3}$ & Trichoderma viride & 13.88 & 53.27 & 18.20 \\
$\mathrm{~T}_{4}$ & Pseudomonas fluorescene & 16.66 & 50.52 & 17.37 \\
$\mathrm{~T}_{5}$ & Nee m leaf extract @ 10\% & 25.00 & 45.78 & 15.46 \\
$\mathrm{~T}_{6}$ & Jatropha leaf extract @ 10\% & 33.33 & 42.30 & 14.22 \\
\hline
\end{tabular}

Table.3 Effect of Bio-agents, botanicals and chemicals on the chilli fresh and dry shoot weight, fresh and dry root weight.

\begin{tabular}{llcccc}
\hline Treatment & $\begin{array}{c}\text { Fresh shoot } \\
\text { Weight }(\mathrm{gm})\end{array}$ & $\begin{array}{c}\text { Dry shoot } \\
\text { Weight }(\mathrm{gm})\end{array}$ & $\begin{array}{c}\text { Fresh root } \\
\text { Weight }(\mathrm{gm})\end{array}$ & $\begin{array}{c}\text { Dry root } \\
\text { Weight }(\mathrm{gm})\end{array}$ \\
\hline $\mathrm{T}_{0}$ & Control & 9.17 & 2.36 & 7.85 & 2.27 \\
$\mathrm{~T}_{1}$ & Carbendazim 50 WP & 20.88 & 9.36 & 18.14 & 9.29 \\
$\mathrm{~T}_{2}$ & Trichoderma harzianum & 16.56 & 5.72 & 13.31 & 6.16 \\
$\mathrm{~T}_{3}$ & Trichoderma viride & 18.15 & 7.82 & 15.88 & 7.86 \\
$\mathrm{~T}_{4}$ & Pseudomonas fluorescene & 17.87 & 6.54 & 14.19 & 6.89 \\
$\mathrm{~T}_{5}$ & Neem leaf extract @ 10\% & 14.39 & 5.71 & 11.86 & 5.25 \\
$\mathrm{~T}_{6}$ & Jatropha leaf extract @ 10\% & 12.57 & 4.30 & 9.83 & 4.11 \\
\hline
\end{tabular}


Fig.1 Pure culture of Fusarium oxysporum f. sp. capsici
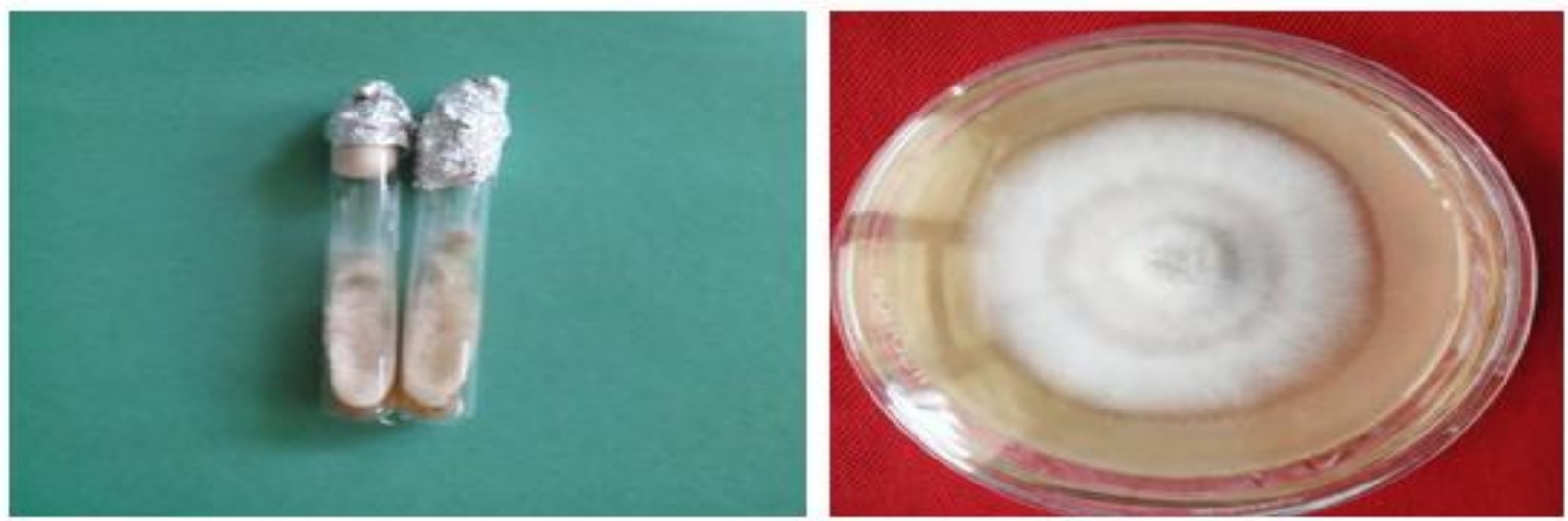

Fig.2 Microscopic view of F. oxysporum f. sp. capsici

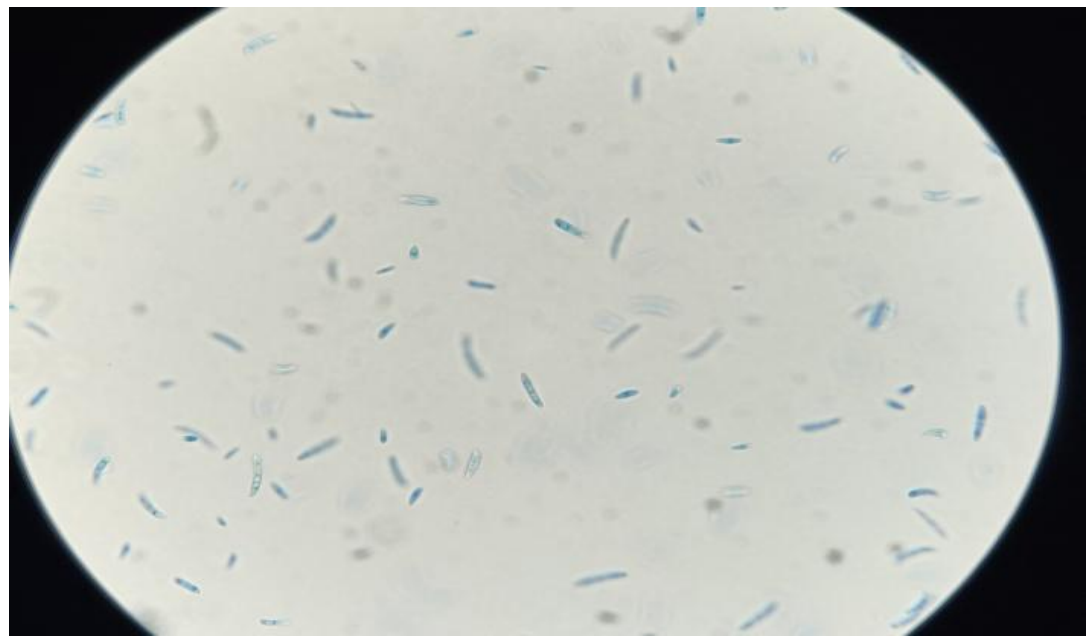

Fig.3 Infected chilli plant root showing browning of the vascular system.

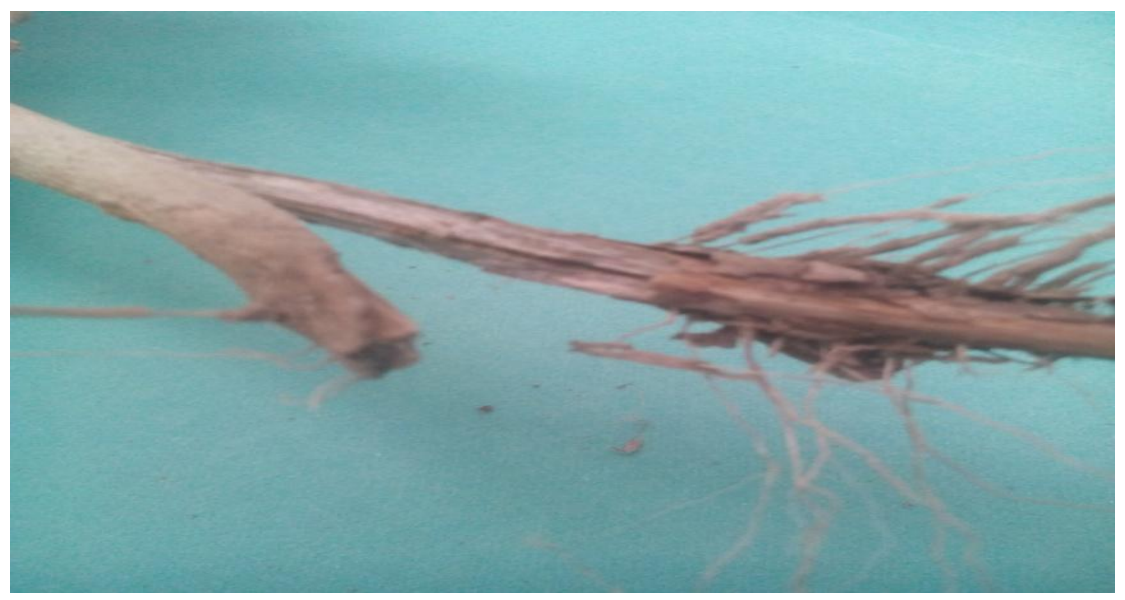


Fig.4 Mycelial growth (mm) of Fusarium oxysporum f.sp. capsici seven days after inoculation as affected by different treatments.

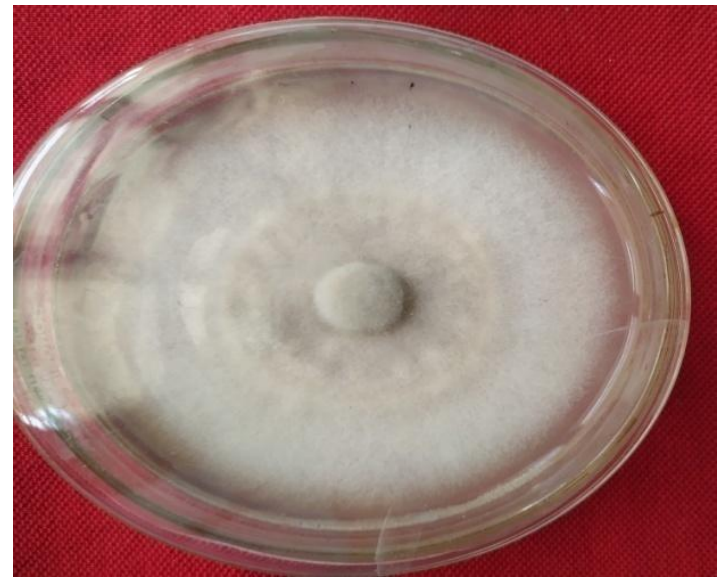

Untreated check (Control)

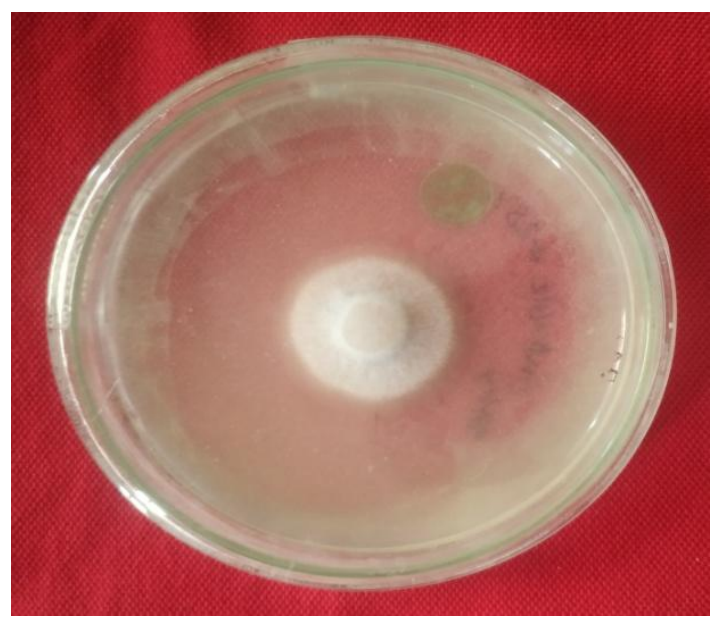

Neem leaf extract @ $10 \%$

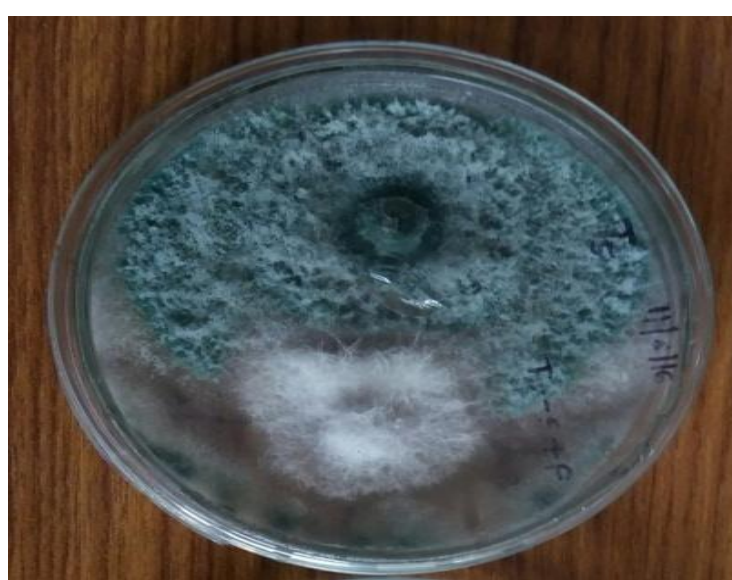

Trichoderma viride

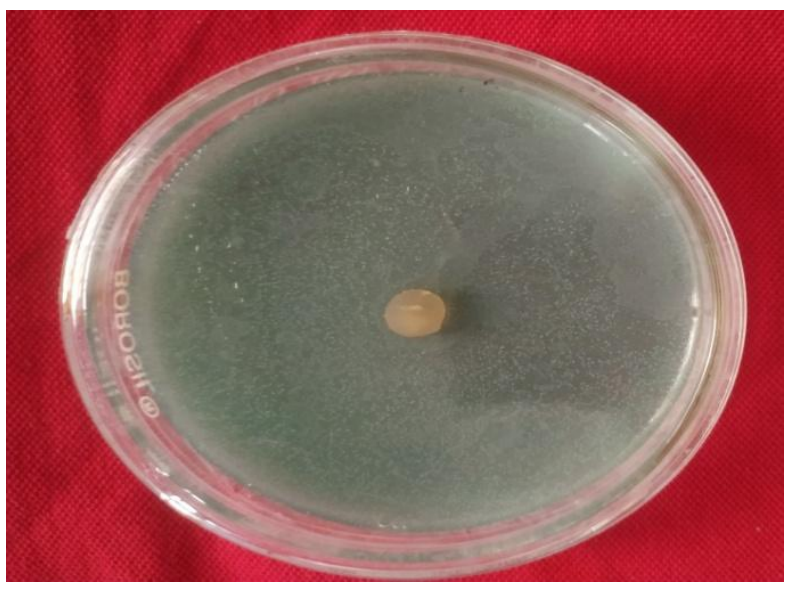

Treated check (Carbendazim50 WP)

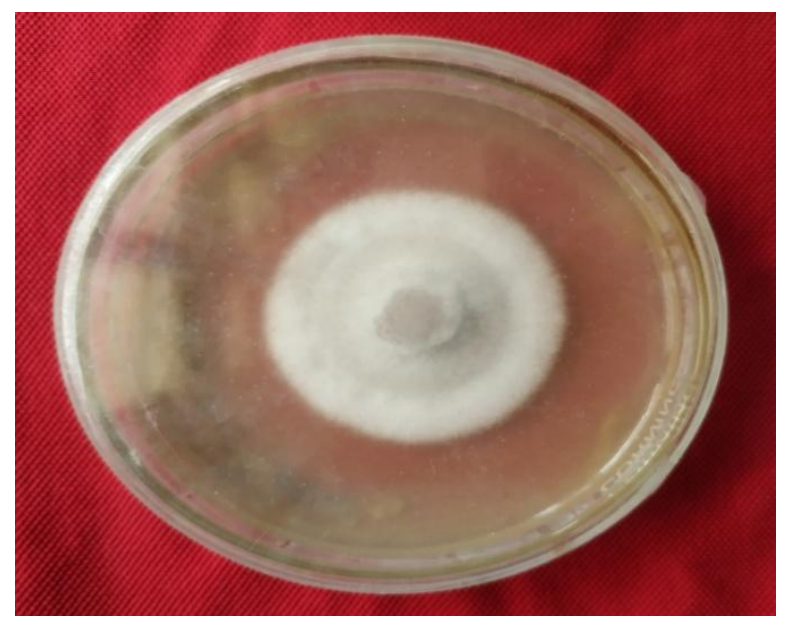

Jatropha leaf extract @ 10\%

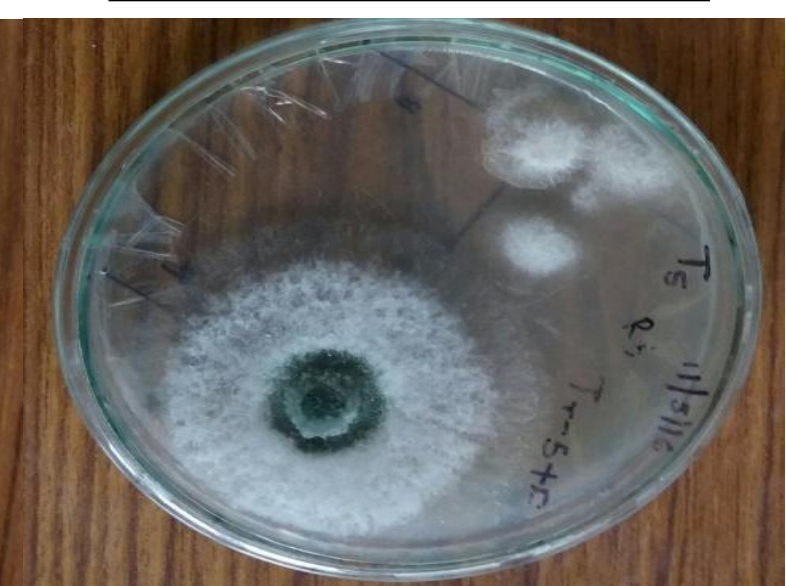

Trichoderma harzianum 


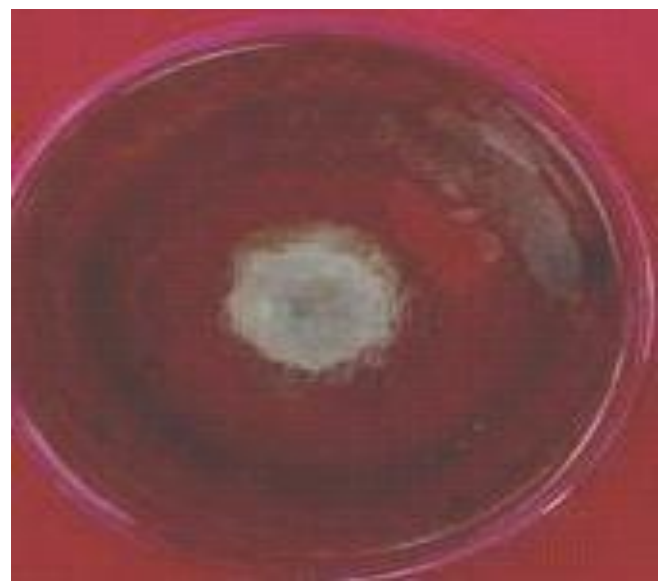

Pseudomonas fluorescens

Fig.5 Plant height and Root length $(\mathrm{cm})$ of chilli as affected by various treatment under field condition at 90 DAT.

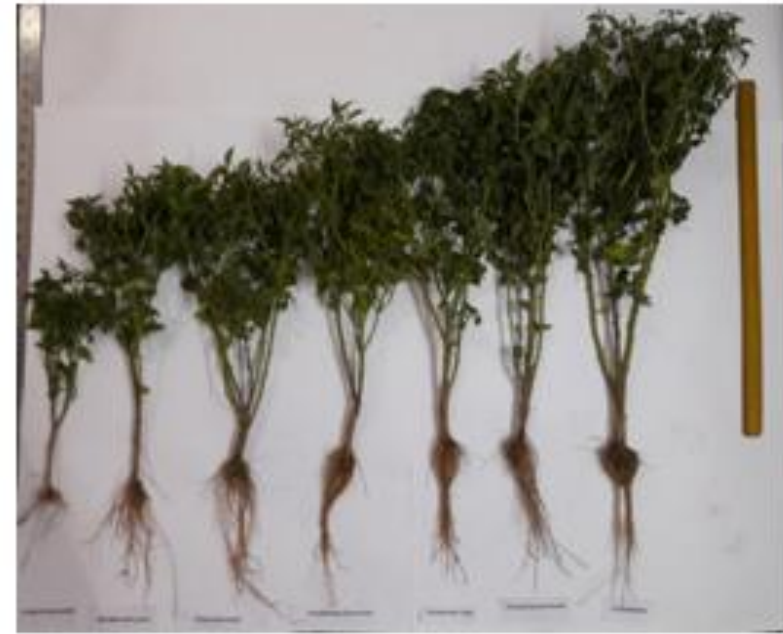

Secretion of extracellular cell degrading enzymes such as chitinase B-1, 3-glucanase, cellulose and lectin by Trichoderma spp. which may have helped mycoparasites in the colonization of their host. The inhibition of pathogen may also be attributed to the production of secondary metabolites by antagonists such as glioviridin, viridian and gliotoxin (Shabir and Rubina, 2010), Tariq et al., (2012), Abdel-Monaim et al., (2012) and Subash et al., (2013).

The antifungal activity of Jatropha curcas has been reported by Siva et al., (2008) while

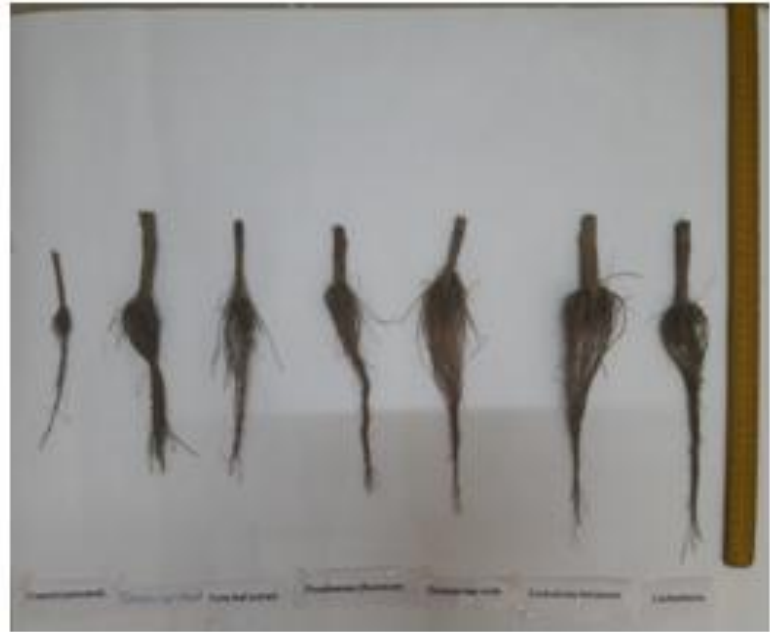

Saetae et al., (2009) reported that jatropha leaf extract can give better control against Fusarium oxysporum f. sp. capsici. The probable reason for such finding may be that $J$. curcas plant contains phenolics, flavonoid and saponins which show notable antifungal, antioxidant, anticancer and anti-inflammatory activities.

The present investigation indicates that application of Trichoderma viride, $T$. harzianum, $P$. fluorescens and botanicals neem leaf extract $10 \%$ and jatropha leaf exraxt $10 \%$ with seed treatment can be used as an 
effective control of wilt disease and to develop eco-friendly strategy for the management of Fusarium wilt of chilli.

\section{Acknowledgement}

The authors gratefully acknowledge Department of Plant Pathology, Sam Higginbottom Institute of Agriculture, Technology \& Sciences (Deemed to be University) Allahabad, India for providing the facility to conduct the research.

\section{References}

Abdel-Monaim, M. F., Abdel-Gaid, M. A. W. and Armanious, H. A. H. 2012. Effect of chemical inducers on root rot and wilt diseases, yield and quality of tomato. Int. J. Agric. Sci. 2(7): 210220.

Ali, M., Jain, S. K., Lal, M., Zuhaib, M., Kumar, S. and Srivastava, A. S. 2014. Survey of media requirement and management of Fusarium wilt of pea. The Bioscan. 9(3): 1213-1216.

Bhat, N. M. and Sivaprakasan, K. 1994. Antifungal activity of some plant extracts. In: Crop innovation techniques and management (Sivaprakasan, K. and Seetharaman, I. eds.). Kalyani publishers, New Delhi, India. PP.335-339.

Chakraborty, M. R. and N. C. Chatterjee. 2007. Interaction of Trichoderma harzianum with Fusarium solani during its pathogenesis and the associated resistance of the host. Asian J. Exp. Sci. 21: 351-355.

Jain, S. K., Khilari, K., Ali, M. and Singh, R. 2014. Response of Fusarium moniliforme the causal organism of bakanae disease of rice against different fungicides. The Bioscan. 9(1): 413-416.

Jamil S, Kumar M. 2010. Evaluation of fungicides against phyllosphere mycoflora of foliage plants. In Biological Forum. 2(1):56-59.

Khan, K. Z., Lal, A. A. and Simon, S. 2014. Integrated strategies in the management of tomato wilt disease caused by Fusarium oxysporum f. sp. lycopersici. The Bioscan. 9(3): 13051308.

Lazarovits, G., Tenuta, M. and Conn. K. L. 2001. Organic amendments as a disease control strategy for soil borne diseases of high-value agricultural crops. Australaian Plant Pathology. 30(2):111-117.

Meena, P. D., Awasthi, R. P., Godika, S., Gupta, J. C., Kumar, A., Sandhu, P. S., Sharma, P., Rai, P. K., Singh, Y. P., Rathi, A. S., Prasad, R., Rai, D. and Kolte, S. J. 2011. Eco-friendly approaches managing major diseases of Indian mustard. World Applied Sciences Journal. 12(8): 1192-1195.

Muthukrishnan, C. R., Thangrai, T. and Chatterjee, R. 1993. Chilli and capsicum in vegetable crops. Maya Prakash Calcutta. pp: 234.

Pal, S. P., Simon, S. and Patel., M. D. 2015. Comparative efficacy of fungicides, selected botanicals and Trichoderma viride against early blight (Alternaria brassicicola) of mustard (Brassica juncea 1.). The Bioscan. 10 (4): 16731675.

Rani, D., G. S., Naik, M. K., Raju, K. and Prasad, P. S. 2007. Prevalence of wilt of chilli and assessment of population dynamics of Fusarium in predominant chilli (Capsicum annum) growing regions of Karnataka. J. Soil Biol. Ecol. 27: 50-61.

Saetae, D. and Worapot S. 2009. Antifungal activities of ethanolic extract from jatropha curcas seed cake. J. Microbiol. Biotechnol. 20(2): 319-324.

Schwartz, H. F., Steadman, J. R., Hall, R. and 
Forster, R. L. 2005. Compendium of bean diseases. 2nd ed. St. Paul: American Phytopatological Society. 120p. SILVA, C.C. da; DELPELOSO, M.J. (Ed.).

Shabir, and Rubina, L. 2010. Biological control of damping-off disease of cabbage caused by Rhizoctonia solani Kuhn. Appl, Biol. Res. 12: 38-41.

Siva, N., Ganesan, S., Banumathy, N. and Muthuchelian. 2008. Antifungal effect of leaf extract of some medicinal plants against Fusarium oxysporum causing wilt disease of Solanum melongena L. Ethnobotanical Leaflets. 12: $156-163$.

Subash, N., Meenakshisundaram, M. and
Sasikumar, C. 2013. In-vitro evaluation of different strains of Trichoderma harzianum as bio-control agents of chilli. International Journal of Biology, Pharmacy and Allied Sciences. 2(2): 495-500.

Tariq, R. R., Razdan, V. K., Tewari, A. K., Efath Shanaz, Z. A., Bhat, Mir G. Hassan and Wani, T.A. 2012. Integrated management of wilt complex disease in bell pepper (Capsicum annuиm L.). Journal of Agricultural Science. 4(7): 141-147.

Vincent, J. M. 1947. Distortion of fungal hyphae in the presence of certain inhibitors. Nature. 159:850.

\section{How to cite this article:}

Abhinav, Pushpendar Singh Shekhawat and Abhilasha A. Lal. 2021. Efficacy of Bio-agents and Botanicals In-vitro and Integrated Disease Management of Wilt Disease of Chilli caused by Fusarium oxysporum f.sp. capsici. Int.J.Curr.Microbiol.App.Sci. 10(07): 503-513. doi: https://doi.org/10.20546/ijcmas.2021.1007.055 